\title{
Transatlantica
}

Revue d'études américaines. American Studies Journal

\section{Leaving the Building: Elvis, Celebrity, Biography, and the Limits of Psychological Autopsy}

Mark Duffett and Paula Hearsum

\section{(2) OpenEdition}

\section{Journals}

Electronic version

URL: https://journals.openedition.org/transatlantica/12921

DOI: $10.4000 /$ transatlantica. 12921

ISSN: $1765-2766$

\section{Publisher}

Association française d'Etudes Américaines (AFEA)

\section{Electronic reference}

Mark Duffett and Paula Hearsum, "Leaving the Building: Elvis, Celebrity, Biography, and the Limits of Psychological Autopsy", Transatlantica [Online], 1 | 2018, Online since 01 September 2019, connection on 31 January 2023. URL: http://journals.openedition.org/transatlantica/12921 ; DOI: https://doi.org/ 10.4000/transatlantica.12921

This text was automatically generated on 31 January 2023

\section{(†)

Creative Commons - Attribution-NonCommercial-NoDerivatives 4.0 International - CC BY-NC-ND 4.0 https://creativecommons.org/licenses/by-nc-nd/4.0/ 


\title{
Leaving the Building: Elvis, Celebrity, Biography, and the Limits of Psychological Autopsy
}

\author{
Mark Duffett and Paula Hearsum
}

Elvis was unhappy. He'd failed in his ambition to become a serious movie actor. His Las Vegas appearances, after just a year, were already boring him. He was isolated, not going anywhere without his bodyguards. And relations were strained with his wife. Not that I ever knew Elvis. I just knew this from reading some books. Edwin Newman in Elvis and Nixon

1 In the mockumentary Elvis and Nixon, long-time NBC newsman Edwin Newman makes a cameo appearance billed as a "legendary TV journalist." With an air of insider experience, he says that in 1970 Elvis Presley was "unhappy," but then he comically undermines himself by adding that he knows as much "from reading some books." Presley continues to inspire an avalanche of published writing, approached only perhaps by the Beatles and Bob Dylan (for surveys see Torgoff, 1982; Duffett, 1999). The singer's ever-expanding library now includes biographies, buddy books, fictional accounts, fan memoires, themed photo collections, tour guides, and recipe books (Hinds, 2001). There is even an educational tome in the popular For Dummies how-to series (Doll). One of the questions repeatedly posed by such volumes is how and why the Memphis legend actually died. This article probes the limits of one particular mode of biographic investigation-psychological autopsy-and considers its relationship to the way in which fans have sought to understand their hero. Using Elvis as a case study, we aim to prompt wider discussion about the efficacy of psychological autopsy as a means of understanding popular individuals. If psychological autopsy is so compromised, why does it remain popular? Our discussion will develop in two parts. The first examines how psychological autopsy departs from objectivity and is 
problematic as theory. The second asks why fans are still interested in discussing why Elvis died, even though psychological autopsy necessarily lacks methodological rigor.

\section{Diagnosing Fatal "Psychache"}

2 Invented by the pioneering psychologist Edwin Shneidman, psychological autopsy is an approach used in clinical practice to understand the role played by an individual's mental predisposition in his or her final days. In 1956-the same year the Elvis burst across the radio airwaves, TV sets, newspapers and cinema screens-the 31-year-old Gengerelli-trained psychologist worked as an intern at the VA West Los Angeles CA hospital (Shneidman, 2001). He was asked by the hospital's Chief to write letters of condolence to two women whose husbands had committed suicide. After examining hospital records and talking to nurses, Shneidman looked into case files at the Coroner's office. Along with a death certificate, police report, autopsy report and photograph, in one he discovered a genuine suicide note. His fascination with the note caused him to borrow around 200 similar documents from the Coroner's records within a week. Soon he extended his first comparative investigation to over 700 such notes. As Shneidman explained:

The fulcrum moment of my suicidological life was not when I came across several hundred suicide notes in a coroner's vault while on an errand for the director of the VA hospital, but rather a few minutes later, in the instant when I had a glimmering that their vast potential could be immeasurably increased if I did not read them, but compared them, in a controlled blind experiment, with simulated suicide notes that might be elicited from matched non-suicidal persons. (Shneidman, 1991 247)

Shneidman's comparative approach to suicide and its antecedents formed the basis of a research paradigm that has been described as "contemporary suicidology" (Shore 15). One of its central methodologies is psychological autopsy (Shneidman and Farberow 80). The phrase describes a practice available to those who assess deaths that might equally have been the result of negligence, accident or suicide. ${ }^{1}$ Alongside any documents about the dead person, psychological autopsies employ interviews with family, friends and associates to try and reconstruct their state of mind. In part, it can be thought of as the pursuit of oral history in the service of illuminating an individual subject's deteriorating mood and will to live.

Shneidman's method was formalized in a sixteen-question checklist (1976). We categorized Shneidman's questions into three groups. The first group broadly gathers evidence about the subject's life history. Beyond identifying basic information about the victim and details of his or her death, Shneidman suggested recording details of the victim's biographic world: personality, lifestyle, inter-personal relationships, siblings, marriage, medical illnesses, medical treatment, psychotherapy, previous suicide attempts. In a second category of investigation, Shneidman suggested focusing on the victim's approach to death: the "death history" in his or her family (fatal illnesses, suicides, ages of death), recent history of and reactions to stress, role of possible triggers (alcohol and drugs), relevant thoughts (fantasies, dreams, comments, premonitions, fears), and assessment of intentionality. Finally, Shneidman advocated including the reactions of informants: were the victim's friends surprised at what happened or did they expect it? The schema can therefore be divided into three categories relating to the victim's life history, inner world, and the conditioned 
expectations of his or her friends. All three aspects are commonly raised in discussions about the deteriorating moods of depressed subjects.

While psychological autopsy began as a psychiatric methodology, the approach has been widely adopted to create accounts of the last days of celebrity figures. Accounts can take the form of, amongst other things, articles, paperbacks and television documentaries. Sometimes they are presented as novels or biopics. ${ }^{2}$ In these various formats, clinical psychologists and others have attempted to reconstruct the last days of famous subjects and assess any propensity towards self-destruction. It is not surprising that Shneidman's approach has been used in attempts to understand celebrity and formed the methodological basis of a number of popular biographies; both the level of public interest and commercial stakes can be very high (Gregory and Gregory).

Elvis Presley is not the only celebrity to become a subject for psychological autopsy, but he is one of the highest in public profile. ${ }^{3}$ While he officially died of "cardiac arrhythmia" (irregular heartbeat), that is not a sufficient explanation for his passing. His medical autopsy was not, moreover, made available to the public (Lacy 90). Few of the facts of Elvis's August 1977 demise are now in doubt, but precisely what killed him remains subject to endless speculation. ${ }^{4}$ Joel Williamson's recent Elvis biography stated: "An amazing array of wild theories sprang up to explain Elvis's untimely death" (16). The whole gamut included the notion that the singer died of heart failure, an overdose, drug interactions ("polypharmacy"), suicide, or bone cancer. Two paperbacks, Parker's Elvis: Murdered by the mob and Urbaney's Who Murdered Elvis?, suggest that the singer was dispatched by someone else. In some popular accounts, he even escapes death and finds another life away from the spotlight (Denisoff and Plasketes). The "What really happened?" question is not just significant in itself, but instead it has implications for Elvis's public reputation. For example, if he had really died unexpectedly of a heart attack, nobody, including the singer himself, would actually be to blame (Williamson 13). In effect, Elvis therefore represents a paradigm case of "equivocal death."

In 2011, the practicing medical hypnoanalyst Ronan J. William published A Psychological Autopsy of Elvis Presley. Subtitling his book "The role of suggestion in the etiology of "psychosomatic disorders," William discussed two syndromes that emerged from the work of John Scott. The abstract of Scott's 1991 article in Medical Hypnoanalysis explained:

One condition discussed is the walking zombie syndrome. This is an allusion to the fact that the individuals have suffered death-like experiences themselves, or have experienced death in the loss of a loved one. In short, some part of the mind has accepted the suggestion of death. They continue to walk around, but act as if "they have no life in them." They often wear dark clothing, have low energy, and are withdrawn and quiet. In the Ponce de Leon syndrome, the emotional development is arrested at an immature stage, and the subject sees the self as child-like and incapable of success. (Scott 45)

Drawing on an analysis of his subject's personal beliefs and insecurities, William reads the singer's life as an example of these two syndromes. They offer theoretical frameworks that guide the author in his task of selection, omission and construction from the material available. Clinical psychologist Dr. Peter Whitmer's The Inner Elvis, in contrast, offers itself as a "psychological biography" of the singer. It shows how Presley's "creative powers and destructive demons stemmed from being the prototypical childhood trauma victim-having lost his twin at birth" (x). Other direct 
psychological autopsies about Elvis include Goldman (1991) and Parker (1994). Together they demonstrate that psychological autopsy is pursued in a variety of different ways.

A number of overview books, such as Thompson and Coles' The Death of Elvis: What really happened (1991), have also hit the marketplace aiming to present fresh evidence and to adjudicate between the different perspectives. Reviewing Thompson and Coles' work, Dave Marsh explained:

At the very least, The Death of Elvis serves the extremely useful purpose of debunking both the gushing nonsense about bone cancer to which many fans still cling and the stupidities of the Elvis suicide theory Goldman has recently retailed. (Marsh xiii)

Though relatively few in number, some books specifically designed to attempt to decide between other accounts of Elvis's life (including his final days) are increasingly common. Patrick Lacy's volume Elvis Decoded: A guide to deciphering the myths and misinformation (2006) is an example of such research, specifically designed for the fan market.

\section{Five Significant Problems with Psychological Autopsy}

9 Hjelmeland et al. (2012) suggested Shneidman's methodology was compromised by significant issues: problems which could emerge in relation to both the interviewers, interviewees, how long the interviews happen after the person's death, standardizing the diagnostic process, and inferring suicide from evidence of mental disorder. Loosely inspired by their critique, the rest of this section explores five significant problems with psychological autopsy in the context of celebrity biography. The first is that there is no fixed, singular method. The second suggests that part of what therefore happens is that readers are asked to trust the investigator. The third is that friends' testimonies can be an unreliable source of evidence. A fourth is that psychological autopsies, in the context of celebrity biography, also draw on published sources. Fifth, the method is exposed as essentially flawed because it necessarily rests on asking its readers to accept questionable inferences. After these five problems are outlined, the section finishes by examining the way in which psychological autopsies draw on shared frames of reference-celebrity biography, dark descent tropes, known aspects of the subject's image-to persuade biography readers.

In the context of celebrity biography, the first issue confronting psychological autopsy is that of method. Unlike a "real" medical autopsy, there is no singular agreed method to follow for the correct creation of a psychological autopsy, an issue further exacerbated by the "open season" approach of commercial biographers, some of whom aim to deductively test a priori propositions, and none of whom sign up to any kind of shared methodological fiat. All forms of psychological autopsy are problematic, but some forms especially so. What such studies therefore rely upon are the justifications, reputation and professional credentials of the writer.

The second issue facing psychological autopsy is that it asks readers to trust the investigator and what they say about the rigor of their particular approach. In theory, psychological autopsy appears to put practicing psychiatrists ahead of standard biographers. After all, they have the professional knowledge and experience necessary to definitively diagnose mental disorders. If the author is a psychiatric expert, we are more likely to trust his or her diagnosis of the mental state of the musician. 
Psychological autopsy therefore confronts its readers with the limits to this trust. As part, for example, of Albert Goldman's efforts to provide an accumulation of circumstantial evidence which demonstrated that Elvis took his own life, Elvis: The Last 24 Hours claimed, "Elvis was chronically depressed and constantly seeking relief from his troubles in some sort of [prescription drug-induced] oblivion that mimics death" (1991 172). Goldman was a professor of English at Columbia University, not a practicing psychiatrist or even a theoretical psychologist. He did not have the professional standing to make pronouncements about his subject's state of mind. Conversely, the esteem in which we might hold colleagues from psychiatry in relation to psychological autopsy should be tempered by a recognition that-at least when they write popular books or participate in media documentaries-they are also engaged in meeting the demands of a commercial audience. ${ }^{5}$ Psychiatric experts are not just inductively piecing together clues to the deteriorating mood of one individual person here; they are systematically profiling their famous case subjects in relation to a stock of theoretical and experiential knowledge about what their (supposedly) suicidal individuals say and do that has been gathered across a whole career. In addition, psychological autopsies are often performed by those outside of the psychiatric profession. If clinical versions tend to temper any hint of a sensationalist delivery, variants of the subgenre have bordered on scandal. A good example of the former is Albert Goldman's lesser known, second biography of Elvis Presley, Elvis: The Last 24 Hours (1991), a paperback in which the author controversially claimed that the star deliberately committed suicide.

Possessing medical credentials does not guarantee that an investigator's account is unbiased. Dr. George Nichopoulos became Elvis's main personal physician in his final decade. According to The New York Times, "Dr. Nick" administered 19,000 pills, including placebos, to Elvis during the singer's last 31 months of life ("Presley's Doctor"). The book When Doctors Kill reports that in 1980 Nichopoulos was indicted on 14 counts of over-prescribing drugs to Memphis celebrities, and has since had his medical license suspended at least twice (Perper 213). In one of the most interesting of the recent contributions to the controversy over Elvis's death, the opioid drugs expert and medical research Dr. Forest Tennant-who had re-examined Dr. Nichopoulos's case on behalf of a defense attorney-argued that Elvis died of gradual complications from a series of traumatic blows to the head:

Progress in modern pain management finally has provided us with enough scientific knowledge about traumatic brain injury (TBI), autoimmune disease, and pain to unravel his medical history. After piecing the evidence together, it is quite clear to me that Elvis's major disabling medical problems stemmed from multiple head injuries that led to an autoimmune inflammatory disorder with subsequent central pain. (Tennant 45)

13 As his evidence, Tennant mentioned four occasions when Elvis fell over in public-two in 1956, one in 1958 and the last in 1967-to which he added that there may have been further such incidents due to a lifestyle that included "rugged" sports, fast bikes and drug overdoses. As a medical professional, Tennant claimed that in his view such episodes could well have caused increasing autoimmune problems and a consequent spiral of physiological consequences and complications. What was interesting, though, was the evidence he gave:

Some of the post-trauma symptoms include memory loss, obsessive-compulsive traits, and irrational or illogical behavior. Elvis demonstrated many of these obsessive-compulsive and erratic behaviors at different times. For example, he gave luxurious gifts to strangers, took spur-of-the-moment flights across country, and 
waged an imaginary campaign against illegal drug dealers. On one occasion in 1970, he impulsively flew to Washington, DC, and called on President Richard Nixon without a prior appointment. He got a "spur-of-the-moment" facelift in 1975. His expenses soared to about $\$ 500,000$ per month, and his entertainment group was essentially bankrupt just before his death due to his lavish, irrational expenditures. (Tennant 52)

Tennant's interpretation therefore draws on erratic moments in the star's life history to infer evidence of a creeping medical problem. By ruling out suicide and replacing it with accident, his theory suggests that Elvis had no existential "psychache," and that neither the singer nor the infamous Dr. Nichopolous were to blame. Even given Dr. Tennant's professional standing, to locate Elvis's impulsive behavior as a result of head trauma rather than personality disposition or celebrity privilege, however, seems rather hard to accept.

14 A third problem for psychological autopsy is whether the testimonies of close friends can be fully trusted in revealing sufficient evidence about the subject's state of mind. In 1994 James Selkin argued, "Psychological autopsy is to suicidology as an interview is to the developing science of psychology" (74). Indeed, psychological autopsy is characterized by the methodological difficulties of using a qualitative method - the interview - in the context in the creation of a deeply personal "psycho-biographic" account. Discussing her view of oral history, Joanna Bornat explained, "There will be bias, partiality, silence, some revelation and much forgetting, but that is the nature of oral history, and for some people its very interest and significance" (240). Celebrity psychological autopsies have obvious problems here. For various reasons, Elvis "insiders" may have tended towards bias, not least to protect their friend's or their own reputations, or for financial gain (Williamson 10). ${ }^{6}$ Taking a distanced stance, the rock critic Dave Marsh dismissed their books as "sheer junk" (xiii). We need not go as far as Marsh to acknowledge that they have created situated, partial and performative accounts. Their evidence does not represent a crystal clear window on the objective reality of Elvis's troubled mind, but instead an attempt to recapture a series of unique and different encounters with the star. This means that not only is the psychological profiler engaged in a process of interpretation and theorizing; each of the informants does those same things too. Their books reflect the impossibility of innocent and unmediated expression:

There is no life without theory. In this sense the "buddy books" are not immune from inter-textual interpretations of Elvis's life. No biographer is innocent... Insider accounts set themselves up against other representations. They aim to "set the record straight." So these books go beyond Elvis to draw on the ideas that previous writers have had about him. The earliest popular books, like Hopkins and Goldman, are therefore outposts on the map. Furthermore, social identity is relational. Elvis Presley was a sensitive man with a highly diverse set of friends. Whether they were intelligent eccentrics like Larry Geller or unreconstructed Southern toughs like Red West, he met each of them on their own particular level. If any reader ever actually befriended the King, it would be likely that they too would come away with a slightly different account. This suggests that Elvis's friends did not reproduce him. Instead they inevitably added something new of their own. (Duffett, 1999 7)

In this context, the information received will depend on the interviewees selected, what they were asked, when they were asked it, to what extent their perceptions had been inflected by shared representations, and what agenda they held as stakeholders in the whole process. A good set of examples here are accounts based on interview testimony by Dr. Nichopoulos (Booth; Breo; Nichopoulos). Because Nichopoulos is both 
medically trained and has been derided by many fans and commentators as a pharmaceutical enabler, his interview statements are likely to offer very different evidence in a psychological autopsy from those by others like Joe Esposito, George Klein and Billy Smith, who were also part of Elvis's inner circle. If such issues were not enough, psychological autopsy interviews raise a significant phenomenological problem: they rely on the interviewees and investigator to translate depressed and suicidal states of mind that they themselves may never have experienced. Part of the problem is that the investigator is attempting to categorize and label an absent person with a psychological disorder on the basis of a partial picture built up from secondhand evidence provided by non-professionals (Canter 1282).

The fourth problem for psychological autopsy is easy to understand: if fresh interviews with the celebrity's inner circles have their problems, information produced by other people-with all the issues of reliability implied-can be used, frequently either to provide central evidence or fill gaps. In the credits at the end of his piece, for example, Dr. Forest Tennant explains:

Most material, other than information directly derived from Elvis Presley's files and records, is from the detailed book, Down at the End of Lonely Street: The Life and Death of Elvis Presley, written by Peter Harry Brown and Pat Broeske. This work was written in 1997 and contains detailed information after years of investigation by these two authors. (Tennant 55)

Even though Tennant's theory ran counter to the claim made in the title of the commercial biography that he drew upon, his diagnosis was based on evidence not from second-hand sources, but from third.

The fifth, and perhaps most significant problem for psychological autopsy is that it presents a "depth model" of the mind which depends on the acceptance of questionable inferences. The method relies on a leap from external indications of the mood, attitude and utterances of the star to a diagnosis of his or her deteriorating inner state of mind. In 2001, Shneidman summarized this conceptual schema: "I believe that suicide is essentially a drama in the mind, where the suicidal drama is almost always driven by psychological pain, the pain of negative emotions-what I call psychache. Psychache is at the dark heart of suicide; no psychache, no suicide" (2001 200). Perhaps the most significant problem for psychological autopsy in general therefore reflects the need to prove a link between the individual's mental disorder and suicidal act. In order to make this inference with any degree of consistency, the same procedures have to be followed each time. As Selkin explains:

One of the reasons that many psychological autopsies terminate inconclusively is that no decision rules have been established for the procedure. An investigator could conclude that a death was suicide on the basis of a single significant clue, whereas another investigator would presume accident (the legal approach) unless 3 or even 13 suicidal clues were present. An investigator who lacks pre-established criteria for identifying a death as suicide or accident is inviting confusion and ambivalence. (Selkin 75)

The issue here, therefore, is that while psychology purports to be a science of mind, psychological autopsy cannot be a scientific procedure. Even when one procedure is consistently and repeatedly followed, the process rarely leads to firm conclusions of its own accord. In terms of the victim's life history, one of the biggest concerns is that the accumulation of circumstantial evidence can never sufficiently prove a particular of cause of death. Common correlation is not the same as certain cause. In other words, many mental disorders do not end in suicide. Also, up to $10 \%$ of suicides happen in spite 
of the victim having no observable mental disorder. Given the ontological, empirical and representational complexity of its subject matter, psychological autopsy primarily rests on an a priori assumption that connects reported memories of the star's final words and behavior with a theory of how suicide happens. The central problem with Shneidman's notion of "psychache" is, as Hjelmeland et al. state, "psychopathology never is a sufficient cause of suicide, although it might be a contributory one."

If psychological autopsy misses its mark in all these ways, how does it establish any persuasive purchase on the reader? It is crucial to understand that in the case of celebrity biography, the methodology essentially operates in the wake of a shared understanding existing parameters. In the final part of this section, the approach will be understood as operating within established frames which are shared by the celebrity's audience. These frames include ideas about celebrity biography, dark descent tropes, and common understandings of the subject's celebrity image. What is interesting here is that the psychological autopsies of celebrity musicians in particular do not just talk about their lives, but can also discuss their creative labor. Consider this example, in which Peter Whitmer considers Elvis's interest in the gospel genre:

Elvis's disintegration continued. His midnight pilgrimage to the funeral home where his mother's body had been embalmed can be regarded as a dramatic form of "death rehearsal". [...] By the same token, Gospel music, more a part of Elvis's life and concerts in his later years, is a musical way of stating that it is O.K. to die. (Whitmer 412)

19 Whitmer's musical diagnosis is not entirely accurate. Elvis had been fascinated by gospel before he recorded a note. In the early 1950s he attended the gospel all-nighters at the Ellis Auditorium in Memphis. He auditioned for the Songfellows quartet in July 1953 and recorded an unreleased country-gospel number ("Satisfied") the next year during his short tenure at Sun Records (Brown 23). His first gospel release for RCA, the Peace in the Valley EP, was recorded one year after "Heartbreak Hotel." Elvis associated himself with gospel long before it became a centerpiece of his 1970s live shows. Whitmer's words have a certain weight, however, in relation to authenticity. According to Allan Moore, authenticity in popular music is not something that is inherent in a song or its performance, but rather a social construct that is applied to the music. Moore located three different forms of ascribed authenticity. First-person authenticity is the presentation of an impression that the music is offered unmediated as a personal expression of its writer or performer. Second-person authenticity occurs when listeners believe that the music has validated their lives and spoken for them. Thirdperson authenticity is successful when a performer is taken as genuinely portraying the world of an absent other. In this context, not only is Elvis framed by fans and commentators as having first person authenticity; psychological autopsies that mention his work also enhance this first person perspective. ${ }^{7}$ In other words, because we assume that Elvis's music-at least in its 1950s and 1970s incarnations-to some extent reflected his life, we also read that life through the filter of the music.

For "psychological biographer" Peter Whitmer, the issue of Elvis's (pre)occupation extends to a concern for music in general as a way that the singer found love:

With [his twin] Jesse's death...xxx he knew that deep down an essential part of him was missing. He would attempt to fill the void of amniotic sensory joy left in him. Especially with music-the sounds that once triggered his first sensations of human connectedness-he would try and try again to recapture the basic, primal experience he had once shared with Jess. For Elvis Presley, with his twin dead and buried, music could never be just an area of interest, a hobby, or even a gift. It 
would be more than a driving force within him. Music, quite quickly in the developing Elvis, would go beyond passion to become compulsion. Music and communicating through music would define him and shape his relationships, helping some, impairing others. Given his natural talent, music, he sensed, could be his vehicle. (Whitmer 41)

Whitmer's words are reminiscent of those of the fictional Dr. Fred Richman who, in the coda to Psycho (Alfred Hitchcock, 1960), discusses Norman's imagined relationship to Mrs. Bates with what one commentator called "an almost sadistic glee" (Greven 77). The actor cast as Dr. Richman, Simon Oakland, was better known for playing TV tough guys, including Sergeant Steve Necclo in Decoy (1957) and Commander Herman Cossler in The Silent Service (1958). To portray the psychiatrist as a wisecracking jock implied that his explanation was simplistic and redundant. Just as audiences had already discovered that Norman dressed as his mother and killed people, so Whitmer's readers already knew that Elvis lost his twin at birth and had a passion for music. Any connection between the two facts is impossible to prove on a scientific level, but makes a relatively comfortable "fit" in terms of the singer's myth. After all, we sense that the Presley's were a family bonded by loss, and that music offered an immediate opportunity for Elvis to build social bonds.

It is easy to say that after his mother died, Elvis Presley pursued a two-decade experiment in finding love, and that while he found communal joy through music, and that eventually his experiment failed so the singer committed a slow suicide. This explanation is mythic; both simplistic and satisfying. Its explanatory power depends on connecting some well-known aspects of Elvis's story with explanations that are easily understood (Ilott). To cloak such explanations in the language of science may make them sound more persuasive, but they still depend on inferences on our part. Ultimately, then, psychological autopsy brings the imprimatur of professional clinical psychological practice to a method that is not scientific, but partial, "it provides the opportunity to cloak an investigation concerned with the soft data of attitudes and feelings in the mantle of exactitude conveyed by medical and physical science, as in the use of the term 'autopsy"' (Selkin 74). What this "cloaking" consist in, crucially, are existing shared understandings of the celebrity's image.

In January 1956 Elvis Presley burst across the firmament of American popular culture with the first single that he recorded for RCA, "Heartbreak Hotel." Written by steel guitarist Tommy Durden and Florida schoolteacher Mae Boren Axton, its composition was based upon a news story in The Miami Herald about a man who had committed suicide by jumping from a window. His suicide note read, "I walk a lonely street." The song was a product of its time. Americans, both young and old, were defining themselves as outsiders, individuals and rebels. One of the biggest youth cultural phenomena of the previous year had been the rise of the "live fast, die young" actor James Dean. In March he debuted in the magnificent East of Eden (Elia Kazan, 1955). In October the more contemporary Rebel Without A Cause (Nicholas Ray, 1955) set a new standard in the expression of teenage angst. Its opening was preceded by the news that Dean's lifeless body had been pulled from the crumpled wreckage of his Porsche Spyder. Dean's speed-induced accident both affirmed his troubled persona, and added an air of melancholy, mystery and romance.

Elvis took a tip from Dean. He served up his own sultry version of death at the end of lonely street with his first major label single. In doing so he contributed to the extended spate of "death discs" and "splatter platters" aimed at adolescents that 
reached well into the next decade (Plopper and Ness). Elvis Presley's performance, of course, was a carefully calculated and soulfully expressed pose. On the single's picture cover, he wore a film noir-style raincoat, complete with collar turned up like Humphrey Bogart in The Big Sleep (Howard Hawks, 1946). The rain that fell on the singer was, of course, meant to convey his desperate state of mind. "Heartbreak Hotel" was a brilliant piece of theatre. It inflected his image with a gloomy undertow for decades to come: in the context of a charismatic performer who had, in part, an existentially entrapped public persona, it was easy to conclude that his private life was like that too - plagued by guilt about his twin brother's death and his father's imprisonment, crushed by the parasitic machinations of his manager, stressed by the formulaic scripts offered by Hollywood, demands of his fans and tell-all exposé written by his bodyguards (Dunleavy), and finally devastated by the death of his mother and exit of his wife. The issue with such well-known information is that Elvis's celebrity image can be seen in two ways: as something that offers clues about his demise or something that misdirects our understandings of his death. In theory, psychological autopsy could be help us to pursue a completely independent course of understanding, but this would be to underestimate the power of a priori frames of reference in shaping commercial discussion.

\section{Appropriating Autopsy: Establishing Closure or Extending Expertise?}

Celebrity biographies based on psychological autopsy are primarily commodities. Martin Torgoff, who ghostwrote Elvis's step-mother Dee Stanley's account (Presley), gave some insights on the process in a later book chapter titled After The Flood, where he explained that writers were vulnerable to "commercial pressures to sensationalize and reveal... [because] people will say or print anything about Elvis, do anything to make a buck" $(1982,20)$. As if to verify this, Torgoff described how his own manuscript had been edited down so that "the gossip and anecdotal elements of the book were now showcased over the analytical and factual because 'that's what people want to read"" (36). He added:

I began to wonder to what degree other Elvis books had been effected by the editorial process, how what had been communicated about the man was either gussied up or watered down, and the implications of this were driven home to me in symbolic terms on the afternoon I was shown the [doctored photo] design for the book cover. (Torgoff 36)

Given that psychological autopsies can be consumed by fan audiences, one possibility is that they are shaped to offer a form of psychological "closure" for individuals in the audience who sense a personal relationship to the star concerned.

Parasocial interaction is an idea that was named in the 1950s and suggests media audience members personally respond to cues offered by performers in the media (Horton and Wohl). In this formulation, fandom represents a role on one side of a pseudo-relationship that at worst can be seen as a form of genuine, unrequited response to the false promises offered by celebrities. Psychologists have continued to pursue and refine Horton and Wohl's ideas (Giles; Stever, 2013). This explanation is, however, highly problematic. Elvis did have a coterie of "superfans," like Cricket Coulter and Sue Wiegert, for example, who regularly talked to their hero in person at the Graceland gates, rather than just writing fan mail (Free; Wiegert). These superfans 
were, however, exceptional. Though comparatively few people met Elvis in person, all had an understanding about what he was like. However, parasocial interaction relies on a notion of personal attachment that has been disputed in relation to celebrity. A media and cultural studies approach has also been used to challenge the assumptions which undergird the theory (Duffett, 2014; Duffett and Hearsum).

The assumptions of parasocial interaction and related ideas define psychological autopsies as an aid to personal closure for grieving fans. When we interviewed the author of one fictionalized account of a troubled rock star's mysterious last days, however, he said that he had received no indication that fans drew on his account to develop a sense of closure about the musician (Myers). Fandom can instead be a quest to understand the context and personalities of inspirational figures or appreciate their creative skills. While everybody fantasizes, and our fantasies can include celebrities, fans are not exceptional and not just dreamers. Not only do they socially network with real people, but they also understand their heroes as powerful, socially valued figures who cannot meet everyone at once. Consequently, while fans prize their heroes as people and experience a connection in relation to them, they are not entrapped by roles that defines their identities as dupes. Perhaps the most significant blow to the parasocial interaction idea is that fans have a strong sense of the realities of their own lives. They are highly cognizant that their star is not actually with them. This has consequences for how we understand the function of psychological autopsies.

Many music publications are aimed at a general readership of which fans make up only a subsection. Given this commercial pressure to sensationalize the truth, scandalous accounts have sometimes been boycotted by fan audiences. Albert Goldman's infamous biography Elvis (1981) is a case in point. Fans publically burned Goldman's book and dismissed it as a set of twisted and fabricated interpretations that missed the truth of a life in favor of outrageous claims about their hero. Despite this, the book was so popular that Avon Books bought the reprint rights for $\$ 1$ million (Walters 27). Goldman's account did not sell to dedicated Elvis fans, disproving the stereotype that they are indiscrimate consumers who will buy anything they encounter bearing their star's name (Jenkins). Dedicated fans may have dismissed Goldman's Elvis biography, but-even though they are not indiscriminate consumers-they do form a steady market for different types of written account; some of the most dedicated Elvis fans are also dedicated Elvis book collectors.

Recent music research has suggested that music fans have a tendency to mythologize and "sanctify" their deceased heroes. Chris Partridge, for example, has claimed that Elvis fans have transfigured their hero "from a bloated, paranoid drug addict who died in less than seraphic circumstances into the glorious and blessed 'Dead Elvis,' the Christian avatar, the American saint, the prophet who walked amongst us for a while" (239). Jennifer Otter Bickerdike's work offers a parallel example: “The more the martyr myth is circulated, the more we [the fans] invest, with money, time and attention, regardless of validity" (63). Claims like these reduce music fans to dreamers, willfully blinded and deluded by their loyalty to their hero to a point where they embrace convenient myths and flatly ignore the truth. If the ontological and epistemological assumptions of psychological autopsy have limited purchase on any substantive claims to truth, the next logical question is that of what purpose this literary subgenre actually serves. Is fan knowledge simply a matter of clinging to myths? After all, fans do not necessarily make the cause of Elvis's death a central topic of discussion (Duffett, 
2012), but sometimes explore why it happened in their attempts to establish empathy for his suffering and to restore dignity to his story.

In reality, dedicated Elvis fans are not worshippers who walk around with rose-tinted spectacles. They may actually know more about the details of the demise of their star than the researchers making such claims. To understand what is happening, it is worth examining two fan pursuits: increasing Elvis's fan base-a practice known as "boosting" (Duffett, 2012)-and to getting closer to the hero. Boosting, the practice of promoting a star's public profile in order to reach more potential followers, in part shapes how fans talk about Elvis. In the compilation, Elvis: Remembered by His Fans, for example, one fan wrote, "The doctors who wrote the prescriptions should be held accountable" (Abrahamian 65). This view suggests Elvis was not entirely to blame for his untimely death. It is not, however, a "sanctification" because it does not suggest that Elvis was free of addiction to medical prescriptions. In other words, the star-who Christopher Partridge uncharitably speaks of as "a bloated, paranoid drug addict who died in less than seraphic circumstances"-is not transfigured as a saint, but perceived as a victim with distinctly human failings. Closeness is no longer simply physical now (Elvis is dead, after all), but it includes the kind of understanding that comes from acquiring more detailed knowledge. Rather than simply conspiring to mythologize, fans wish to know the truth: to get as close as is currently possible to a picture of what happened-a picture that is, necessarily, provisional and constantly evolving both for them as individuals and for their community. Fans therefore collect facts and interpretations about the life of their hero. Reading psychological autopsies can be seen as a practice that adds to their gradually accumulating stock of knowledge. They have therefore pursued goals on two fronts: maintaining the icon's reputation in public, while seeking out the frankest details of his life and demise to enhance their own understanding. ${ }^{8}$

Learning more and more allows dedicated Elvis fans to assist less experienced enthusiasts in making or assessing interpretations, to accumulate cultural capital that can be deployed within the fan community (Fiske, 1992), and to adjudicate between different claims offered in the media, or pursue vernacular theories. To this end, fans themselves constantly compare, contrast and piece together evidence about the end of Elvis's life. His inner circle of friends, relatives, and co-workers have been interviewed on many occasions by newspapers, magazines, fan clubs, television stations and websites. They offer opinions like this one, which Elvis's drummer Ronnie Tutt made to an Australian fan club:

He needed to go around the world [on tour]. He needed a complete change back from that [routinized management] mentality that we discussed earlier. And I think that's part of the thing-I personally feel that in a way he died of boredom. He had very little to look forward to. I saw it in his life too. I had dinner with him. I saw the girl that was with him. She was just there for the ride. She didn't care about him in my opinion, in my observation. When you've surrounded yourself with people like that, then I think... He didn't know how to become seriously depressed, because he wasn't that kind of person - I think it had a major effect on him. Another part of the tragedy is that he was trapped in the image that he had created. (Deelen)

Comparing such statements allows fans to assemble their own stock of knowledge that enhances their understanding of the Memphis superstar. Anything that fans find like this is part of an ongoing quest for greater knowledge, one that puts aside myths, commercial imperatives, and other extraneous considerations in a search for a more honest and satisfying explanation. 
In this piece we have suggested psychological autopsy is a deeply flawed methodology, but we all use stories to explain things. Elvis remains, as per the title of John Fiske's essay, "a body of controversy" (Fiske, 1993). When it comes to the historic events of August 1977, his story never quite settles, it seems, precisely because the imagination of it is our own, a death that cannot be reduced to a static stock of facts or a simplified system of myths. His "equivocal death" that has much at stake because it potentially says a lot about his life. The process of assembling psychological autopsies does not therefore stop with clinical experts or commercial products, but is an open-ended practice pursued by those who consume Elvis information. In her 1978 memoir, Elvis: For The Good Times, superfan Sue Wiegert offered a relatively nuanced, four-page testimony from registered nurse Carole Neely outlining some key aspects of the icon's medical condition: anxiety, insomnia, high blood pressure, twisted colon, prescription drug intake, glaucoma and cardiac congestion. This, we suggest, was not simply for prurient or voyeuristic interest, or even because findings from Elvis's autopsy were kept secret. It was, rather, to respond to theories that cast his life in a negative light. Rather than cynically assuming Presley's pharmaceutical descent was an indication of flawed character (selfishness, hypocrisy and indulgence), Neely casts his story as a tragedy, ending it by saying, "A broken heart can be fatal, loneliness can kill" (Wiegert 6). In her reading, Elvis neglected his health because he could not feel love in his life. Fans like Wiegert and Neely use a variant of Shneidman's approach to offer an interpretation of their hero's passing, not necessarily for reasons that are related to personal "closure" or mass commerce-Wiegert's memoire is self-published by the Blue Hawaiians for Elvis fan club-but because it helps fans both understand and support their hero as a talented and flawed individual.

\section{BIBLIOGRAPHY}

ABRAHAMIAN, Mike. Elvis: Remembered by His Fans. Burbank: Sivle Books, 2007.

BICKERDIKE, Jennifer Otter. Fandom, Image and Authenticity: Joy Devotion and the Second Lives of Kurt Cobain and Ian Curtis. Basingstoke: Palgrave MacMillan, 2014.

BОOTH, Stanley. “The King is Dead! Hang the Doctor!” The Complete Elvis. Ed. Martin Torgoff. New York: Delilah Books, 1982, p. 70-85.

BORNAT, Joanna. “Oral History.” Biographical Research. Ed., John Goodwin. London: Sage, 2012, p. 239-258.

BREO, Dennis. Extra-ordinary Care. Chicago: Chicago Review Press, 1986, p. 46-62.

BROWN, Shane. Elvis Presley: A Listener's Guide. Norwich: Createspace, 2014.

CANTER, David. "Psychological Autopsies." Encyclopedia of Forensic Sciences. Eds. Jay Siegle and Pekka Saukko. London: Elsevier, 2000, p. 1281-1290. Available at: http://core.ac.uk/download/ pdf/54310.pdf. Accessed 19 September 2019. 
DEELEN, Arjun. “Interview with Ronnie Tutt." Elvis Australia, 19 December 2009. http:// www.elvis.com.au/presley/interview_ronnietutt.shtml. Accessed 19 September 2019.

DENISOFF, Serge R., and George PLASKETES. True Disbelievers: The Elvis Contagion. New Brunswick: Transaction Publishers, 1995.

DOLL, Susan. Elvis for Dummies. Hoboken: Wiley, 2009.

DUFFETT, Mark. "Boosting Elvis: A Content Analysis of Stories from One Elvis Presley Fan Club Magazine.” Participations, vol. 9, no. 2, 2012, p. 317-336.

---. “Celebrity: The Return of the Repressed in Fan Studies?" The Ashgate Companion to Fan Cultures. Eds Linda Duits, Koos Zwaan, and Stijn Reijnders. Farnham: Ashgate, 2014, p. 163-180.

---. "Reading the Rock Biography: A Life without Theory?" Conference paper. Robert Shelton Memorial Conference, Liverpool: Institute of Popular Music, 1 May 1999.

DUFFETT, Mark, and Paula HEARSUM. “Alas, Poor Richard: Fandom, Personal Identity and Ben Myer's Novelization of Richey Edwards' Life Story.” Volume!, vol. 14, no. 1, p. 65-84.

DUNLEAVY, Steve. Elvis: What Happened? New York: Ballantine, 1977.

Elvis and Nixon. Dir. Allan Arkush. Written by Alan Rosen. With Rick Peters (Elvis Presley), Bob Gunton (Richard M. Nixon), Alyson Court (Priscilla Presley), and Edwin Newman (himself). Dufferin Gate Productions / Elvis Nixon Productions, 1997.

FISKE, John. "The Cultural Economy of Fandom." The Adoring Audience: Fan culture and Popular Media. Ed. Lisa Lewis. London: Routledge, 1992, p. 30-49.

---. Power Works, Power Plays. London: Verso, 1993.

FREE, Cathy. “Utah All Shook Up Over Elvis.” Deseret News, 8 August, 2002, p. B1.

GILES, David. "Parasocial Interaction: A Review of the Literature and a Model for Future Research.” Media Psychology, vol. 4, no. 3, 2002, p. 279-305.

GOLDMAN, Albert. Elvis. New York: McGraw-Hill, 1981.

---. Elvis: The Last 24 Hours. St Martin's Press: New York, 1991.

GREGORY, Neal, and Janice GREGORY. When Elvis Died: Media Overload and the Origins of the Elvis Cult. New York: Pharos Books, 1992.

GREVEN, David. Psycho-sexual Hitchcock: Male Desire in Hitchcock, De Palma, Scorsese and Friedkin. Austin: University of Texas Press, 2013.

HALPERIN, Ian, and Max WALLACE. Love \& Death: The Murder of Kurt Cobain. London: Allison \& Busby, 2000.

---. Who Killed Kurt Cobain? The Mysterious Death of an Icon. New York: Kensington Publishing, 1998.

HINDS, Mary Hancock. Infinite Elvis: An Annotated Bibliography. Chicago: Acapella, 2001.

HJELMELAND, Heidi, Gudrun DIESERUD, Kari DYREGROV, Birthe L. KNIZEK, and Antoon A. LEENAARS. "Psychological Autopsy Studies as Diagnostic Tools: Are They Methodologically Flawed?" Death Studies, vol. 36, no. 7, 2012, p. 605-626.

HORTON, Donald, and Richard WOHL. "Mass Communication and Parasocial Interaction." Psychiatry, vol. 19, no. 3, 1956, p. 215-229.

ILOTT, Irene. "Did Elvis Die of Boredom?" British Journal of Occupational Therapy, vol. 70, no. 10, 2007, p. 415. 
JENKINS, Henry. Textual Poachers: Television Fans and Participatory Cultures. New York: Routledge, 1992.

LACY, Patrick. Elvis Decoded: A Guide to Deciphering the Myths and Misinformation. Bloomington: Author House, 2006.

MARSH, Dave. Elvis. London: Omnibus Press, 1992.

MCCUTCHEON, Linda, Rense LANGE, and James HOURAN. "Conceptualization and Measurement of Celebrity Worship." British Journal of Psychology, vol. 93, 2002, p. 67-87.

MOORE, Allan. “Authenticity as Authentication.” Popular Music, vol. 21, no. 2, 2002, p. 209-223.

MYERS, Ben. “An Interview with 'Richard' Author Ben Myers.” 2014. http://pop-musicresearch.blogspot.co.uk/2014/03/an-interview-with-richard-author-ben.html. Accessed 19 September 2019.

NICKELL, Joe, and John FISCHER. Crime Science: Methods of Forensic Detection. Lexington: University Press of Kentucky, 2013.

NICHOPOULOS, George. The King and Dr. Nick. Nashville: Thomas Nelson, 2010.

PARKER, John. Elvis: Murdered by the Mob. New York: Arrow Books, 1994.

PARTRIDGE, Christopher. The Lyre of Orpheus: Popular Music, the Sacred, and the Profane. New York: Oxford University Press, 2014.

PERPER, Joshua. When Doctors Kill: Who, Why, and How. New York: Copernicus Books, 2010.

PLOPPER, Bruce, and M. Ernest NESS. "Death as Portrayed to Adolescents through Top 40 Rock and Roll Music." Adolescence, vol. 28, no. 112, 1993, p. 793-807.

PRESLEY, Dee, Billy, Rick, and David Stanley, as told to Martin Torgoff. Elvis: We Love You Tender. London: New English Library, 1980.

“Presley’s Doctor Acquitted on All Prescription Charges." New York Times, 5 November 1981, p. A14.

SCOTT, John. "Missing Links in the Treatment of Depression: II." Medical Hypnoanalysis Journal, vol. 6, no. 2, 1991, p. 45-64.

SELKIN, James. "Psychological Autopsy: Scientific Psychohistory or Clinical Intuition?" American Psychologist, vol. 49, no. 1, 1994, p. 74-5.

SHNEIDMAN, Edwin. Comprehending Suicide: Landmarks in $20^{\text {th }}$-Century Suicidology. Washington, DC: American Psychological Association, 2001.

---. "A Life in Death." The History of Clinical Psychology in Autobiography. Ed. Eugene C. Walker. Pacific Grove, CA: Brooks/Cole, 1991, p. 225-292.

----. Suicidology: Contemporary Developments. New York: Grune and Stratton, 1976.

SHNEIDMAN, Edwin, and Norman FARBEROW. Cry for Help. New York: McGraw-Hill, 1965.

SHORE, Peter. "Suicidology: An Oral History." Psy. D. Dissertation. Ann Arbor: Chicago School of Professional Psychology, 2009.

STEVER, Gayle. “Celebrity Worship: Critiquing a Construct." Journal of Applied Social Psychology, vol. 41, no. 6, 2011, p. 1356-1370.

---. "Twitter as a Way for Celebrities to Communicate with Fans: Implications for the Study of Parasocial Interaction.” North American Journal of Psychology, vol. 15, no. 2, 2013, p. 339-354. 
TENNANT, Forest. “Elvis Presley: Head Trauma, Auto-immunity, Pain, and Early Death.” Practical Pain Management, vol. 13, no. 5, 2013, p. 44-55.

THOMPSON, Charles, and James COLE. The Death of Elvis: What Really Happened. London: Robert Hale, 1991.

TORGOFF, Martin. "After the Flood: Elvis and His Literary Legacy.” The Complete Elvis. Ed. Martin Torgoff. London: Delilah Books, 1982, p. 18-39.

---, ed. The Complete Elvis. New York: Delilah Books, 1982.

URBANEY, Stephen. Who Murdered Elvis? Bloomington: iUniverse, 2008.

WALTERS, R. “The Myth Lives On.” New York Times Book Review, vol. 86, no. 33, 1981, p. 27.

WHITMER, Peter. The Inner Elvis: A Psychological Biography of Elvis Aaron Presley. New York: Hyperion, 1996.

WIEGERT, Sue. Elvis: For The Good Times. Los Angeles: Blue Hawaiians for Elvis, 1978.

WILLIAM, Ronan. A Psychological Autopsy of Elvis Presley: The Role of Suggestion in the Etiology of Psychosomatic Disorders. Springfield: American College of Forensic Examiners Institute, 2011.

WILLIAMSON, Joel. Elvis: A Southern Life. Oxford: Oxford University Press, 2015.

\section{NOTES}

1. Other methods of investigating causes of death include final scene investigations, sometimes called "Equivocal Death Analysis," a method that some researchers see as more likely to produce conclusive results (Selkin), while others see as less conclusive (Canter).

2. For example, the feature film Last Days (Van Sant, 2006) portrays the descent of Kurt Cobain and Ben Myers' 2014 novel Richard offers a portrait of the disintegrating inner world of the Manic Street Preachers' guitarist Richey Evans.

3. In 1962 a suicide investigation team examined the death of Marilyn Monroe. The panel concluded that she was subject to depression and mood swings, and in conjunction with her autopsy report, her death was a probable suicide (Nickell and Fischer 264). In popular music, amongst other musicians, the Nirvana frontman Kurt Cobain has been subjected to various psychological autopsies, usually, in his case, aiming to decide whether the death was a suicide or murder. For example, alongside Nick Broomfield's artfully shambling film documentary Kurt and Courtney (1998), there have been various paperbacks including Ian Halperin and Max Wallace's two books Who Killed Kurt Cobain? (1998) and Love \& Death: The murder of Kurt Cobain (2000).

4. A good example here is the title of the book that Elvis was reading when he died (Lacy 22). If such factual information has already become lost to the historical record, there is little hope for piecing together Elvis's inner world.

5. One relevant example is "celebrity worship syndrome" (McCutcheon, Lange, and Houran), the pathologizing label given to an invented disorder that seemed perhaps more connected with media stereotypes and mass cultural thinking than any immediate precedents from the discipline of psychology (Stever, 2011).

6. Many of the Elvis "buddy books" were co-written with commercial writers such as journalists who translated the reminiscences of the Memphis Mafia into acceptable commodities. In a parallel case, describing Broomfield's documentary Kurt and Courtney (1998), Jennifer Otter Bickerdike (117) noted that "what grabs the viewer is the seeming unending utilization of Cobain as a means to gain individual fame and identity." 
7. The irony here, of course, is that Elvis was not a songwriter; it is his soulful performance that is convincing.

8. A parallel example of this collective, dualistic approach was the fandom's historic approach to the bootleg circulation of the CBS TV special, Elvis In Concert, which was filmed during his final US concert tour in June 1977 and broadcast within months of his death. Although the peaks of his vocal performance reached their usual high standard, CBS footage showed Elvis looking very ill and out of shape. His estate released a CD of the material in 1992, but they tried to keep the footage out of circulation and did not pursue a DVD release. Bootleg versions were circulated, however, within Elvis fan clubs. Club members knew that Elvis in Concert might repel would-be fans. They did not, however, shun it themselves, as they knew it was a window on the life of a man that they loved. Now the concert surfaces regularly on YouTube.

INDEX

Subjects: La boîte à musique

\section{AUTHORS}

\section{MARK DUFFETT}

University of Chester, UK

PAULA HEARSUM

University of Brighton, UK 